\title{
AN APPARENT DECLINE OF NORTHERN LEOPARD FROGS (Rana pipiens) ON THE RAFFERTY DAM MITIGATION LANDS NEAR ESTEVAN, SK
}

DANNA M. SCHOCK, School of Life Sciences, Arizona State University, Tempe, AZ, USA 85287-4601 E-mail: <danna.schock@asu.edu> and TRENT K. BOLLINGER, Canadian Cooperative Wildlife Health Centre, Western College of Veterinary Medicine, University of Saskatchewan, Saskatoon, SK S7N 5B4 Email: <trent.bollinger@usask.ca>

\section{Introduction}

Northern Leopard Frogs (Rana pipiens) are found throughout much of North America in habitats associated with permanent streams, marshes, ponds and lakes. 9,14 They are large, green to brownish frogs with welldefined, pale-bordered spots on their backs. (Figure 1) Their call is often likened to someone running their finger across an inflated balloon and is accented with occasional chuckles and grunts. In Saskatchewan, they breed in May and early June, and the tadpoles usually metamorphose in

late July and August. They attain sexual maturity at two to three years of age. Unlike Boreal Chorus Frogs (Pseudacris maculata, Figure 2) and Wood Frogs (Rana sylvatica, Figure 3), which over-winter under leaf-litter and snow, Northern Leopard Frogs overwinter at the bottom of water bodies deep enough to not freeze solid to the bottom. While the species may be familiar to many outdoor enthusiasts, the Northern Leopard Frog has met a far larger audience via its dubious honour of being the frog of choice for

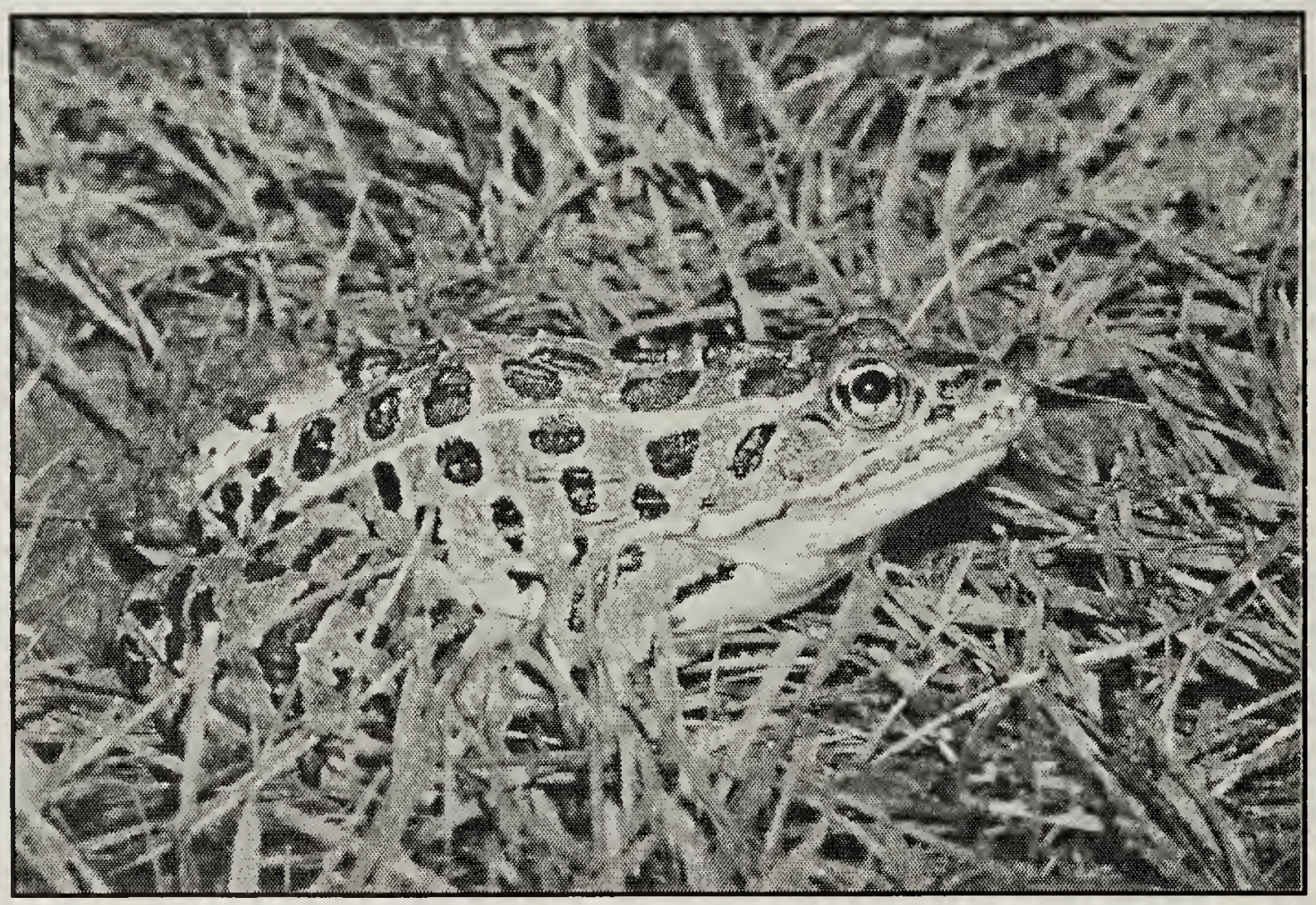

classroom dissections.

Like all amphibians, Northern Leopard Frogs are integral components of $t h$ e i $r$ ecosystems, serving as predator, prey and host. Northern Leopard Frog tadpoles eat

Figure 1. Northern Leopard Frog

R. E. Gehlert 


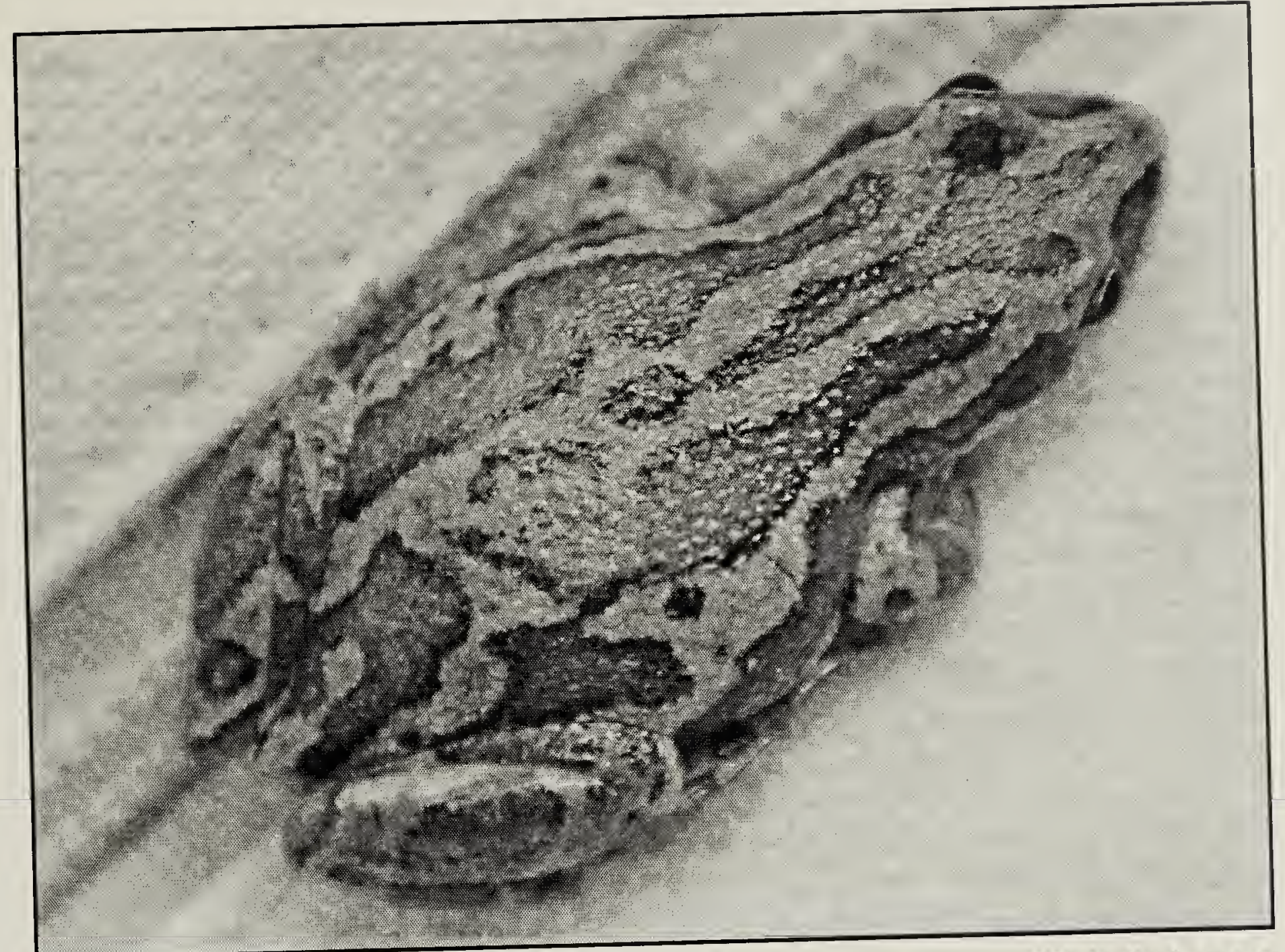

Figure 2. Boreal Chorus Frog

Michelle Lanoie

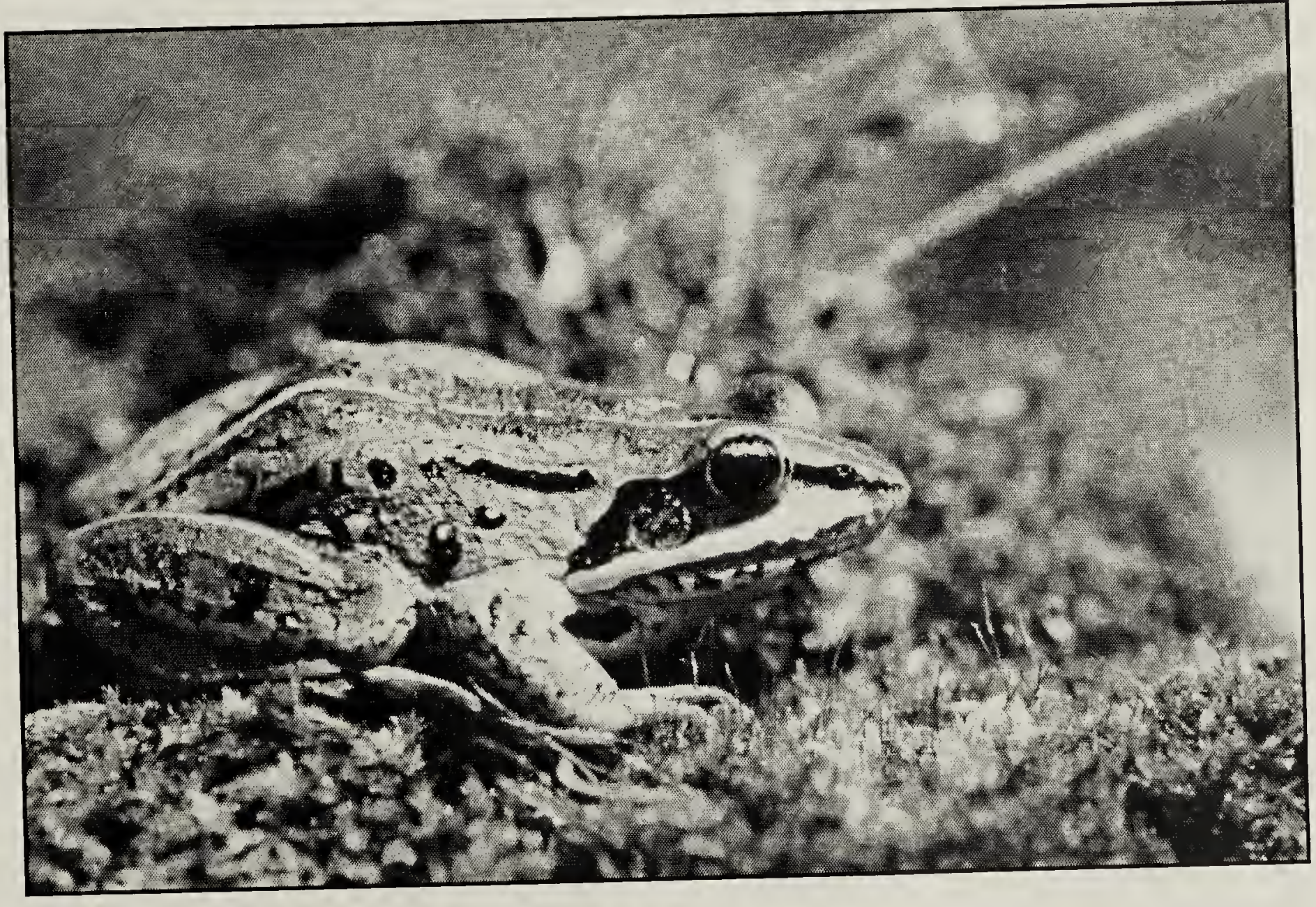

Figure 3. Wood Frog

R. E. Gehlert 
mostly aquatic vegetation and algae and, in turn, are eaten by many organisms including fish, garter snakes (Thamnophis $s p$ ), herons, grebes, small mammals, and aquatic insects such as dragonfly larvae. During metamorphosis, their digestive tract undergoes a major transformation which accommodates their carnivorous post-metamorphic diet. After metamorphosis, Northern Leopard Frogs eat most manner of creatures small enough to swallow including insects, spiders, snails, small fish, and even other Northern Leopard Frogs. Many of the same reptile, bird and mammal species that prey on tadpoles also prey on the frogs.

Northern Leopard Frogs are intricately linked with another essential component of all ecosystems: parasites. One parasite of some notoriety is the trematode Ribeiroia, which has been connected with inducing certain kinds of limb deformities in amphibians. ${ }^{10,16}$ Although Ribeiroia is not a new parasite, there is concern that its numbers are increasing in some parts of North America due to changes in wetlands that promote large populations of snails. ${ }^{11}$ Large populations of snails may result in large populations of Ribeiroia because this parasite requires a snail host to complete part of its lifecycle. An increasing number of snails may mean an increasing number of Ribeiroia and consequently, an increasing number of frogs with limb deformities.

Unfortunately, Northern Leopard Frog numbers, like those of many amphibian species, have declined dramatically over much of their range in the recent past. ${ }^{18}$ The geographic range of Northern Leopard Frogs contracted in the late 1970 s and early 1980s. The cause(s) of the contraction has not been established but retrospective hypotheses include all the "usual suspects" associated with amphibian declines and other losses of biodiversity: land use change, global climate change, pathogen outbreaks, environmental contamination, overcollection from wild populations, and introduction of invasive species (e.g., predatory fish). Excellent reviews of these topics appear in Collins and Storfer, Green, and Semlitsch. 6,9,17 Although amphibians are notorious for their highly variable year-to-year recruitment ${ }^{1}$ (the addition of sexually mature individuals to a population through birth and survival to sexual maturity), persistent downward population trends for extended periods of time have made it clear that Northern Leopard Frogs are decreasing in numbers across much of their historic range.

In 2002, the Committee on the Status of Endangered Wildlife In Canada (COSEWIC) classified the Northern Leopard Frog as a species of "Special Concern" in the prairie provinces because the "species remains widespread but has experienced a severe contraction of range and loss of populations, particularly in the west. This has been accompanied by increased isolation of remaining populations, which fluctuate widely in size." 7 In Saskatchewan, Northern Leopard Frogs are ranked as "S3 - rare to uncommon" by the Saskatchewan Conservation Data Centre (Saskatchewan Environment). ${ }^{15}$

Here we report an apparent Northern Leopard Frog population decline in southeastern Saskatchewan on the Rafferty Mitigation Lands (RMLs). The RMLs, along with the Alameda Mitigation Lands, were acquired by the Province of Saskatchewan in the late 
1980 s to offset loss of wildlife habitat due to flooding from the Rafferty and Alameda dams on the Souris River and Moose Mountain Creek, respectively. ${ }^{12}$ A total of approximately 4000 discontinuous hectares were acquired, the majority of which were cultivated at the time of purchase. Ongoing management objectives include converting the land to more structurally and biologically diverse habitat (e.g. grasslands, wetlands, tree stands) in the hopes of creating appropriate wildlife habitat. The RMLs consist of three parcels of land, each named after the nearest town: Macoun, Midale and Halbrite. Our report concerns only the Macoun and Halbrite parcels because the Midale parcel is small and does not include appropriate Northern Leopard Frog habitat.

\section{Methods}

The Macoun and Halbrite parcels were first visited in May of 1999 by D.M. Schock while conducting wildlife surveys for Saskatchewan Wetland Conservation Corporation (now part of the Saskatchewan Watershed Authority). In addition to incidental amphibian sightings recorded during bird and aquatic invertebrate surveys, a formal amphibian survey was conducted as part of the 1999 wildlife survey. ${ }^{12}$ Site visits from 2000-2004 were conducted as time permitted but special efforts were made to visit the RMLs in mid-May each year because Northern Leopard Frogs are active and vocal at this time of year, and because large numbers of Northern Leopard Frog carcasses were found at the Macoun site in mid-May 1999 and 2000.

By 2002, it was apparent that there were far fewer Northern Leopard Frogs on the RMLs than there had been in 1999 and 2000, prompting us to collect Northern Leopard Frog data from other locations to use as "reference sites".
The reference sites allowed us to determine whether Northern Leopard Frog numbers also were low at other sites that historically had populations of Northern Leopard Frogs. Reference sites were locations known to have Northern Leopard Frogs in the previous one to two years and to have habitat characteristics comparable to the RMLs. They were located in areas that facilitated visiting them during the course of other activities, thereby improving the frequency with which we could visit the sites. Three reference sites were chosen: Grasslands National Park - West Block, Saskatchewan Landing Provincial Park, and Eagle Creek (northwest of Saskatoon). Like visits to the RMLs after 1999, visits to reference sites were made during recreational outings or in conjunction with unrelated research projects. Although visits to the reference sites were made as time permitted, special efforts were made to visit at least one reference site within a few days of visiting the RMLs.

Most site visits involved walking the perimeter of the water body and looking, listening, and dip-netting for amphibians during daylight hours, May-August. In 2003 and 2004, some sites were also seined $(10 \mathrm{~m}$ wide $x$ $2 \mathrm{~m}$ deep nets pulled through the water with ropes) as part of a research project on Tiger Salamanders (Ambystoma tigrinum). To prevent spreading pathogens and other organisms among sites, nets and boots were cleaned of large material and then disinfected with a $10 \%$ bleach solution. Aseptic collection and handling techniques were employed when dealing with live or dead animals.

To improve our basis for comparison, we also acquired Northern Leopard Frog reports submitted to the Saskatchewan Conservation Data Centre 
Table 1. Northern Leopard Frogs encountered per visit to the Macoun and Halbrite parcels of the Rafferty Mitigation Lands 1999-2004, and three reference sites 2001-2004.

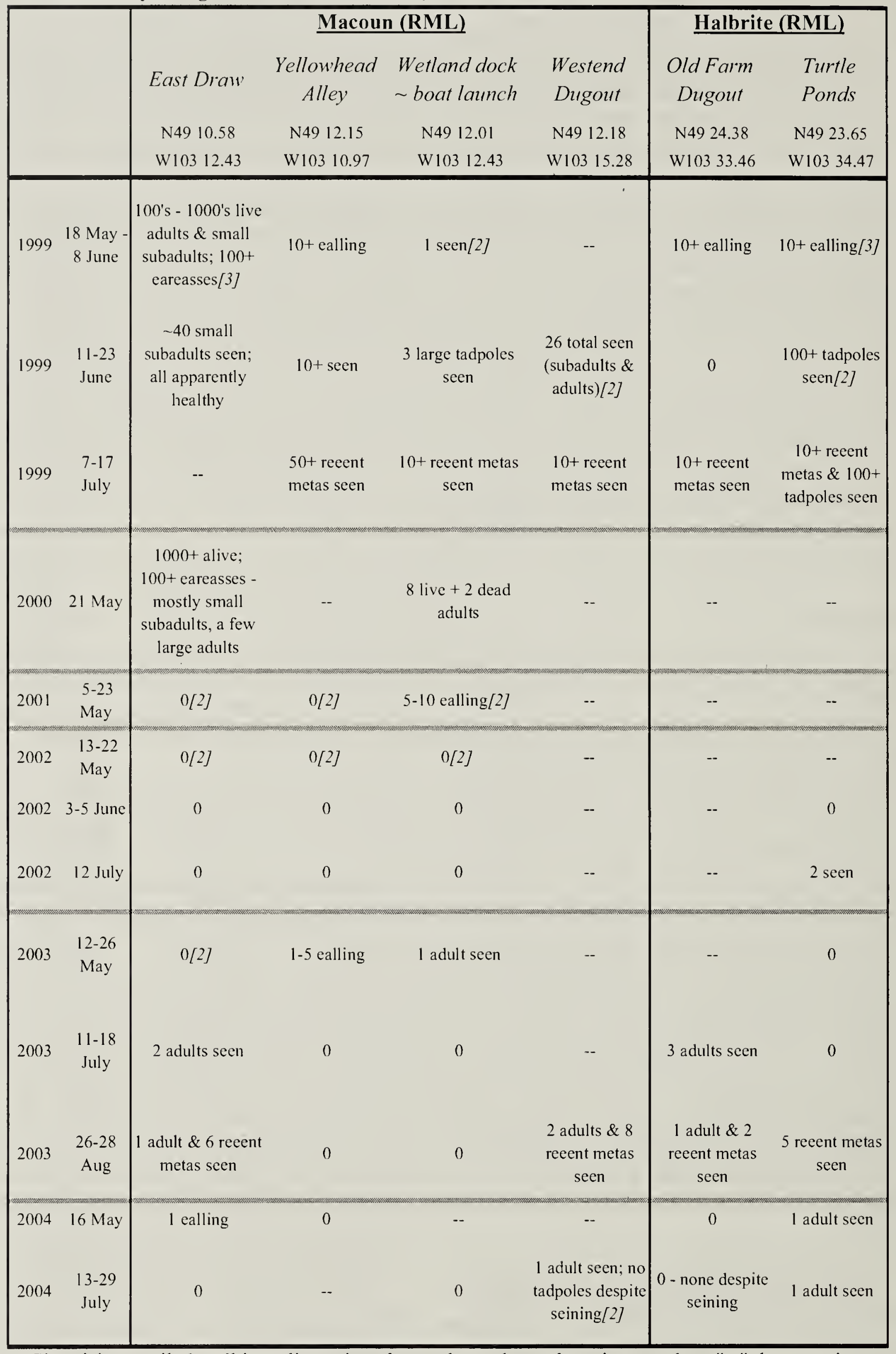

- Site visits entailed walking+dipnetting along edge unless otherwise noted. • "--" denotes site not visited during time interval. • "metas" = recent metamorphs. i.c. young-of-the-ycar frog life stage, not tadpoles. - "+" denotes that at least that many individuals were eneountered. 
Table 1. Continued

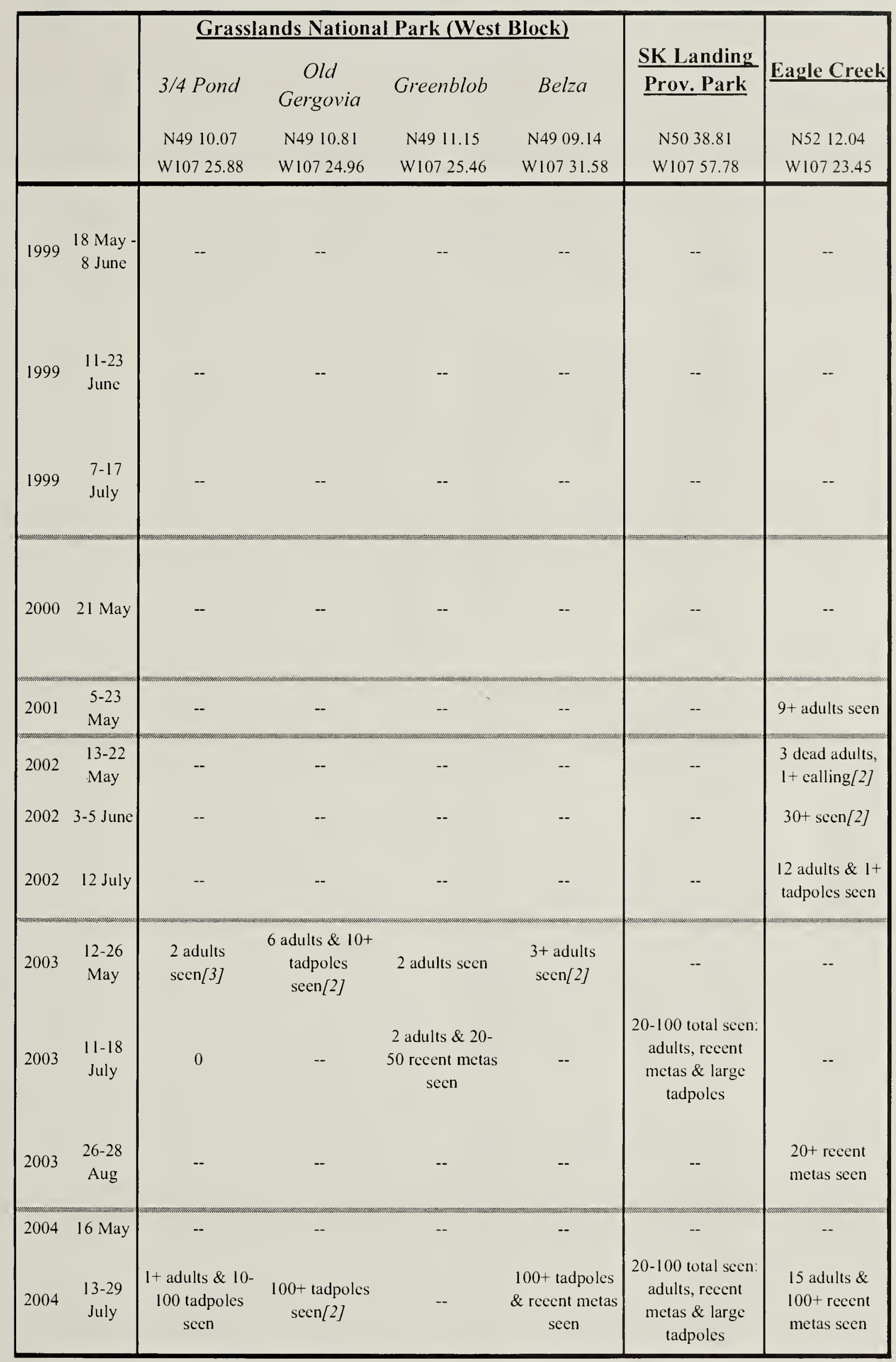

- [2], [3] = \# of times site visited during time interval if more than once. Visits at least 2 days apart. If site was visited more than onee during an interval, the highest number of individuals eneountered in a single visit is reported. - Pond names were eoined by DMS for eonvenienee and do not neeessarily eorrespond to any other names. 
(Saskatchewan Environment) 20012004.

We would like to highlight that our report does not cover the entire range of Northern Leopard Frogs in Saskatchewan and we do not report on the numerous sites we visited over the years where we did not find Northern Leopard Frogs despite apparently suitable habitat.

\section{Results}

The numbers of Northern Leopard Frogs encountered on the RMLs dropped steeply after 2000 , despite increased surveillance effort (Table 1). Only two individuals were found in 2002 despite four visits to the RMLs in that year and no tadpoles were found in 2004 despite seining ponds where Northern Leopard Frogs had previously been found.

In sharp contrast to the RMLs, Northern Leopard Frog numbers at the three reference sites were not low in 2002-2004 (Table 1). Incidental sightings at other locations and reports obtained from the Saskatchewan Conservation Data Centre (Table 2) also suggest that Northern Leopard Frogs were found elsewhere in southern Saskatchewan, including in the Estevan area. Even the Weyburn Golf Course was blessed with 100's of Northern Leopard Frogs in $2003 .^{2}$

Large die-offs on the RMLs in 1999 and 2000 probably contributed to the low numbers of Northern Leopard Frogs on the RMLs in 2001-2004. On the very first visit to the Macoun parcel of land, 18 May 1999, hundreds of dead Northern Leopard Frogs were found (Table 1). A second, larger die-off was encountered in May of 2000 . The numbers of dead frogs in 1999 and
2000 easily reached into the 100's within $300 \mathrm{~m}$ stretches of shoreline.

In 1999 and 2000, a total of approximately 65 dead or lethargic frogs were collected and necropsied. The examinations revealed that many had lesions consistent with lethal viral infections. Details of pathology and virus characterization will be published elsewhere but briefly, the virus was confirmed to be a novel strain of Frog Virus 3 (FV3), a ranavirus. Ranaviruses (Family Iridoviridae) are a large genus of globally distributed viruses. Members of this genus can cause mass mortality events in fish, amphibian, and reptile species, although infections are not always lethal nor do they always cause overt signs of disease. ${ }^{3,5,8}$ A pathogen outbreak, such as a ranavirus outbreak, would have been encouraged by high numbers of frogs in the late 1990s. We know there were high numbers of Northern Leopard Frogs in 1999 and 2000 based on the large numbers of carcasses and we assume there were high numbers in 1998 because the 100's of carcasses found in the spring of 1999 were animals at least one year old.

Northern Pike (Esox lucius) and Western Painted Turtle (Chrysemys picta) carcasses also were found at least once every year from 1999 to 2004 on the Macoun parcel, particularly at the "East Draw". Unfortunately, these carcasses were too decomposed to confidently identify a cause of death, or were too far out in the water to be collected. We never encountered more than three dead turtles or pike during a given site visit so we do not know whether the carcasses were part of larger mortality events. However, we feel it is important to note that the turtle and pike carcasses were found in the 
Table 2. Other sightings of Northern Leopard Frogs in Saskatchewan 2000-2003.

\begin{tabular}{|c|c|c|c|c|c|}
\hline $\begin{array}{l}\text { Nearest town } \\
\text { or permanent } \\
\text { location }\end{array}$ & Site name & $\begin{array}{l}\text { Land location/ } \\
\text { coordinates }\end{array}$ & Date of visit & $\begin{array}{c}\text { Number } \\
\text { observed |1] }\end{array}$ & $\begin{array}{l}\text { Source of } \\
\text { record [3] }\end{array}$ \\
\hline Ceylon & Ceylon 2 & N49.35; W 104.77 & 20-Jul-01 & $\sim 70$ & $\mathrm{a}$ \\
\hline Ceylon & Ceylon 3 & N49.56; W 104.61 & 24-Jul-01 & abundant[2] & $\mathrm{a}$ \\
\hline Craik / Elbow & $\begin{array}{l}\text { Elbow PFRA } \\
\text { pasture }\end{array}$ & N51 04; W106 19 & 20-Aug-00 & 7 & d \\
\hline $\begin{array}{l}\text { Cypress Hills } \\
\text { Inter-prov. Park }\end{array}$ & $\begin{array}{l}\text { Belanger } \\
\text { Creek Area }\end{array}$ & NE-29-08-26-03 & 15-Jul-00 & $\begin{array}{c}100+\text { in } \\
\text { Belanger } \\
\text { Creek area }\end{array}$ & $\mathrm{c}$ \\
\hline Esterhazy & Esterhazy 14 & N50.59; W 102.10 & 15-Aug-01 & $<40$ & $\mathrm{a}$ \\
\hline Esterhazy & Esterhazy 3 & N50.75; W 101.94 & 30-Jul-03 & abundant[2] & $b$ \\
\hline Estevan & Estevan Rec2 & N49.08; W 103.08 & 19-Jul-01 & $<40$ & a \\
\hline Estevan & $\begin{array}{l}\text { Estevan } \\
\text { OMP6 }\end{array}$ & N49.10; W 102.80 & 19-Jul-01 & $<40$ & a \\
\hline Estevan & $\begin{array}{l}\text { Estevan Nat6, } \\
14\end{array}$ & N49.16; W 102.86 & 19-Jul-01 & $100+$ & $\mathrm{a}$ \\
\hline Estevan & $\begin{array}{l}\text { Estevan } \\
\text { OMP7 }\end{array}$ & N49.06; W 102.88 & 20-Jul-01 & $<40$ & $\mathrm{a}$ \\
\hline Kipling & Kipling 2 & N50.15; W102.14 & $30-\mathrm{Jul}-03$ & abundant[2] & $\mathrm{b}$ \\
\hline Mortlach & Mortlach 3 & N50.31; W 106.07 & 8-Aug-01 & abundant[2] & $\mathrm{a}$ \\
\hline Mortlach & Mortlach 1 & N50.33; W106.07 & 8-Aug-01 & $<40$ & $\mathrm{a}$ \\
\hline Radville & Radville 18 & N40.31; W 104.29 & 27-Jul-0l & abundant[2] & $\mathrm{a}$ \\
\hline Radville & Radville 12 & N49.41; W 104.31 & 27-Jul-0l & abundant[2] & a \\
\hline Radville & Radville 1 & N49.39; W 104.34 & 25-Jul-03 & $<40$ & $b$ \\
\hline Radville & Radville 10 & N49.29; W 104.23 & $25-\mathrm{Jul}-03$ & $<40$ & b \\
\hline Radville & Radville 3 & N49.30; W 104.30 & 25-Jul-03 & abundant[2] & $\mathrm{b}$ \\
\hline Radville & Radville 7 & N49.49; W 104.29 & 25-Jul-03 & $<40$ & $b$ \\
\hline Regina & Johnson Pond & $\begin{array}{l}\sim 15 \mathrm{~km} N W \text { of } \\
\text { Regina }\end{array}$ & 21-Aug-01 & $20+$ & d \\
\hline Smeaton & Smeaton 2 & N53.86; W104.62 & 12-Aug-03 & $<40$ & $\mathrm{~b}$ \\
\hline Stoughton & Stoughton 4 & N49.83; W 102.89 & 1-Aug-01 & abundant[2] & $\mathrm{a}$ \\
\hline Stoughton & Stoughton 1 & N49.67; W102.95 & 29-Jul-03 & $<40$ & $\mathrm{~b}$ \\
\hline Weyburn & Weyburn 7 & N49.26; W104.01 & 26-Jul-0l & $<40$ & a \\
\hline Weyburn & Weyburn 10 & N49.29; W104.61 & 26-Jut-01 & $<40$ & $\mathrm{a}$ \\
\hline Weyburn & Weyburn 6 & N49.30; W103.98 & 26-Jul-03 & $<40$ & $b$ \\
\hline
\end{tabular}

- [1] Number observed includes all life stages except eggs. - [2] Assumed by original source to be mostly young-of-the-year recent metamorphs. - [3] Sources: a = SK CDC: Stet Donald, D. Forsyth; b =SK CDC: D. Forsyth; $c=$ J. Pepper; d = D.M. Schock. 
same locations as the Northern Leopard Frog die-offs.

\section{Discussion}

Northern Leopard Frogs, like most other amphibians, have highly variable recruitment from year to year, due in part to their ability to forego breeding in poor years (e.g., during droughts). Accordingly, wide fluctuations in numbers are to be expected, including years when few animals are encountered. ${ }^{1}$ Our data suggest, however, that the low number of Northern Leopard Frogs at the RMLs in 2002-2004 was not a widespread or even regional phenomenon, and therefore not readily attributable to weather patterns such as drought or cool temperatures. We feel that the massive die-offs in 1999 and 2000 contributed to the low numbers 2001 2004. One cause of the die-offs was a ranavirus outbreak, but we may never know the complex of ecological mechanisms that precipitated the dieoffs in 1999 and 2000.

Northern Leopard Frogs exist in metapopulations, clusters of populations loosely connected to each other through migration in exceptional years. ${ }^{1}$ Recovery of the RMLs population may rely on migrants from other populations recolonizing the area. Unfortunately, recolonization events may be rare for species living in highly fragmented habitats, such as the prairies, because tracts of land between suitable habitat patches may be inhospitable and therefore impossible to traverse. The result is isolated populations in areas that cannot be recolonized when something "goes wrong" such as when a pond dries or a pathogen gets the upper hand.

We hope that what we have reported here is just a low point in one population's cycle and that the frogs will recover in the next few years. We also hope that this note will encourage others to take interest in the amphibians they encounter. The Canadian Amphibian and Reptile Conservation Network (CARCNet) website ${ }^{4}$ provides a great introduction to "herping" and contains excellent information on habitat, geographic distribution, and identification (including frog calls). Enthusiastic readers are encouraged to report their amphibian sightings to their provincial/ territorial governments (e.g., Saskatchewan Environment Conservation Data Centre), provincial museums, or to FrogWatch, a member of the NatureWatch volunteer monitoring program. ${ }^{13}$ Volunteerbased programs like FrogWatch do not require large time commitments from participants and the data collected can shed much-needed light on population stability and health, especially when the data are used in conjunction with data from long-term monitoring programs. However, the nature of these volunteer programs makes them inappropriate stand-ins or substitutes for rigorous systematic surveys and monitoring programs conducted by government agencies. Therefore, we end our report with a plea for provincial and federal authorities in Saskatchewan to undertake rigorous surveys and implement longterm monitoring programs for Northern Leopard Frogs, a species that is floundering throughout most of western North America. Without such efforts, it is not possible to make informed predictions about the longterm stability of Northern Leopard Frogs in Saskatchewan, nor is it possible to evaluate how population declines like the one we report here factor into those predictions.

\section{Acknowledgements}

We gratefully acknowledge the financial support of the United States 
National Science Foundation. Wildlife research permits were obtained from Saskatchewan Environment in all years. All 1999 data have been included here with permission from the Saskatchewan Watershed Authority, and T. Cobb, S. Davis, G. McMaster, and J. Morissette. All data from 2000-2004 were collected during personal recreational site visits or during site visits for research projects not related to this report. We wish to acknowledge J. Pepper with the Saskatchewan Conservation Data Centre for helpful discussions about the manuscript and access to Northern Leopard Frog reports submitted to the Conservation Data Centre; D. Forsyth and D. Donald with Environment Canada for permission to include their sightings; Grasslands National Park for permission to work in the park, and especially P. Fargey and R. Sissons for logistical support. We thank $M$. Anderson, T. Currie, R. Kydd, L. McLeod, M. Paskaruk, J. Pepper, A. Ringdahl, M. Scheck and T. Stitt for assistance and company in the field over the years. Finally, the manuscript benefited greatly from thoughtful suggestions by M. Boley, J.P. Collins, and an anonymous reviewer.

1. ALFORD, R.A. and S.J. RICHARDS. 1999. Global amphibian declines: A problem in applied ecology. Annual Review of Ecology and Systematics 30:133-165.

2. BAILEY, M. 2004. Northern Leopard Frogs in a golf course water hazard. Blue Jay 62:43-45.

3. BOLLINGER, T.K., J. MAO, D. SCHOCK, R.M. BRIGHAM, and V.G. CHINCHAR. 1999. Iridovirus infection in tiger salamanders in Saskatchewan: Pathology, isolation and molecular characterization of a novel ranavirus. Journal of Wildlife Diseases 35:413-429
4. CANADIAN AMPHIBIAN AND REPTILE CONSERVATION NETWORK (CARCNET) WEBSITE. www.carcnet.ca (Accessed 30 June 2005)

5. CHINCHAR, V.G. 2002. Ranaviruses (Family Iridoviridae): Emerging coldblooded killers. Archives of Virology 147:447-470.

6. COLLINS, J.P., and A. STORFER. 2003. Global amphibian declines: Sorting the hypotheses. Diversity and Distributions 9:89-98.

7. COMMITTEE ON THE STATUS OF ENDANGERED WILDLIFE IN CANADA WEBSITE. Www.cosewic.gc.ca (Accessed 30 June 2005)

8. GREEN, D.E., K.A. CONVERSE, and A.K. SCHRADER. 2002. Epizootiology of sixty-four amphibian morbidity and mortality events in the USA, 1996 2001. Annals of the New York Academy of Science 969:323-39.

9. GREEN, D.M. (ed.) 1997. Amphibians in Decline: Canadian studies of a global problem. Herpetological Conservation Number One. Society for the Study of Amphibians and Reptiles, Saint Louis, MO.

10. JOHNSON, P.T., K.A. LUNDE, E.M. THURMAN, and others. 2002. Parasite (Ribeiroia ondatrae) infection linked to amphibian malformations in the western United States. Ecological Monographs 72:151-168.

11. JOHNSON, P.T.J and J.M. CHASE. 2004. Parasites in the food web: linking amphibian malformations and aquatic eutrophication. Ecology Letters 7:521-526.

12. MORISSETTTE, J., T. COBB, D. SCHOCK, and S. DAVIS. 2000. Wildlife 
monitoring and inventory of the RaffertyAlameda mitigation lands. Final report to Saskatchewan Wetland Conservation Corporation and Saskatchewan Environment \& Resource Management.

13. NATUREWATCH WEBSITE. www.naturewatch.ca (Accessed 30 June 2005).

14. RUSSELL, A.P. and A.M. BAUER. 2000. The Amphibians and Reptiles of Alberta, A Field Guide and Primer of Boreal Herpetology. University of Calgary Press, Calgary.

15. SASKATCHEWAN CONSERVATION DATA CENTRE WEBSITE. www. biodiversity.sk.ca (Accessed 30 June 2005).
16. SCHOTTHOEFER, A.M., A.V. KOEHLER, C.U. METEYER, and R.A. COLE. 2003. Influence of Ribeiroia ondatrae (Trematoda:Digenea) infection on limb development and survival of Northern Leopard Frogs (Rana pipiens): effects of host stage and parasite-exposure level. Canadian Journal of Zoology 81:11441153.

17. SEMLITSCH, R.D. (ed.). 2003. Amphibian Conservation. Smithsonian Press, Washington DC.

18. STUART, S.N., J.S. CHANSON, N.A. COX, and others. 2004. Status and trends of amphibian declines and extinctions worldwide. Science 306:1783-1786

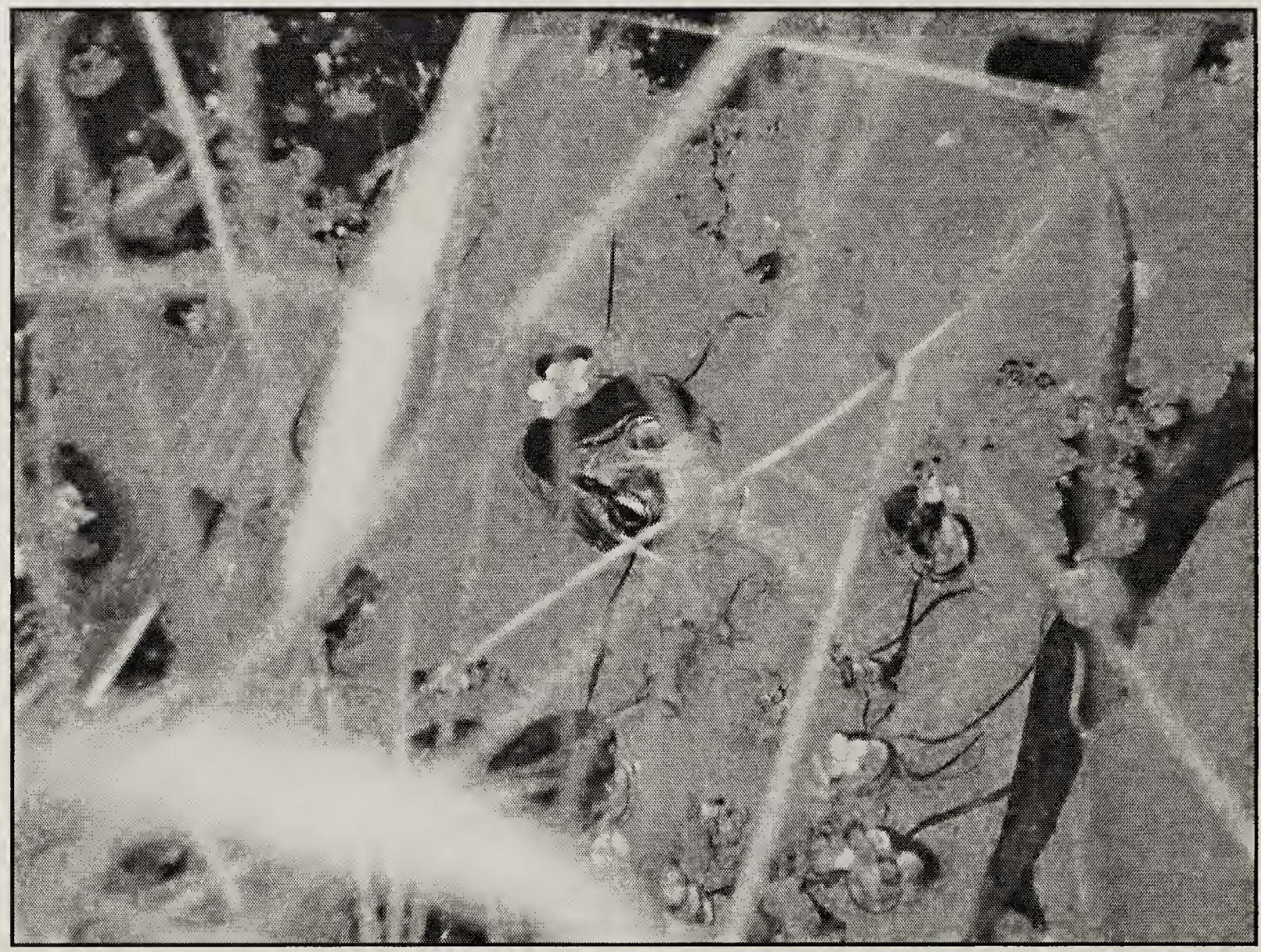

Wood Frog blending in with aquatic vegetation

Shelley Kaplar 